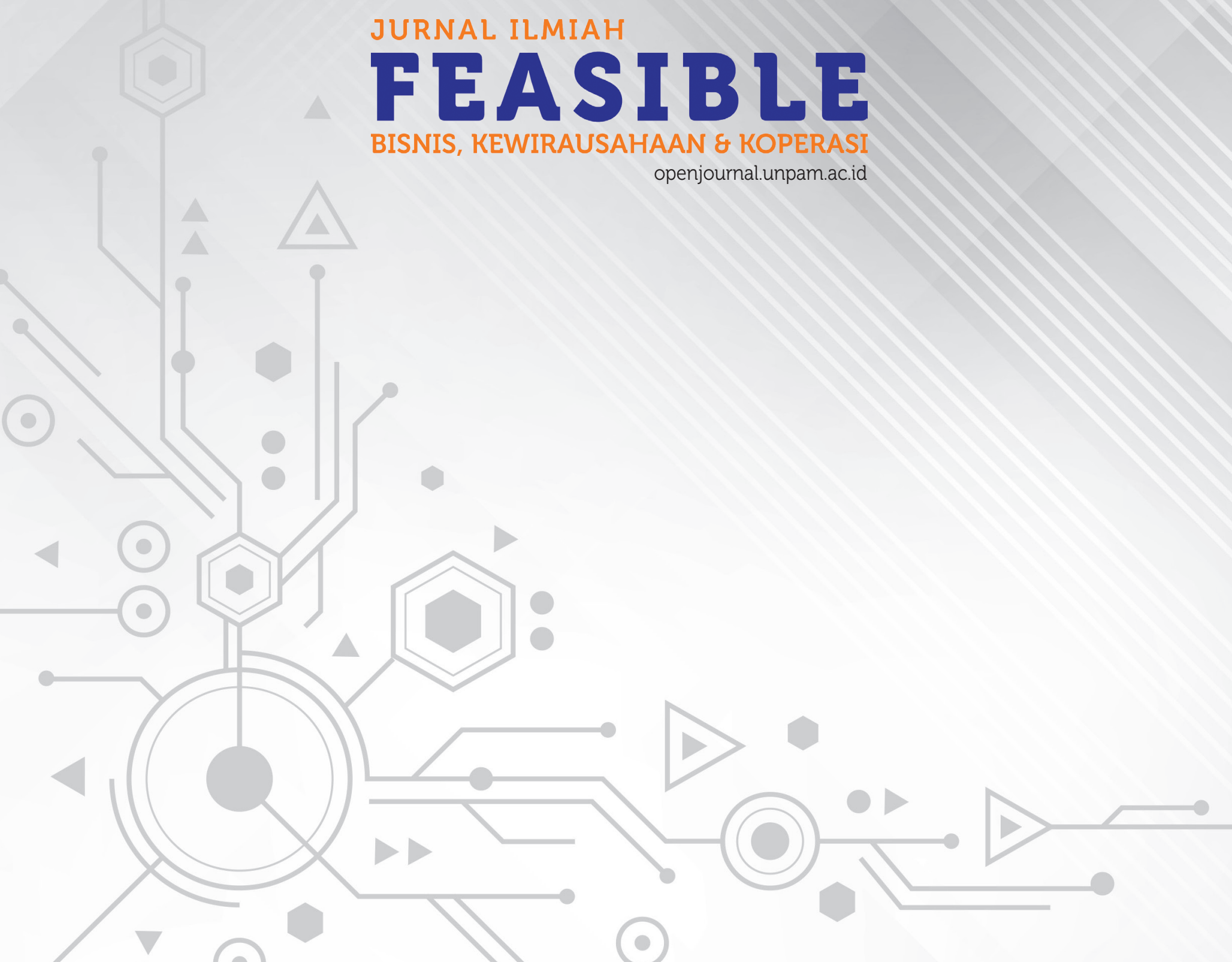




\title{
PENGARUH KUALITAS LAYANAN PENDIDIKAN TERHADAP KEPUASAN PESERTA DIDIK DI SMA ISLAM CIKAL HARAPAN BUMI SERPONG DAMAI
}

\author{
Gatot Kusjono; Eni Sudjiani \\ Universitas Pamulang \\ dosenoo434@unpam.ac.id; Sudjiani.eni70@gmail.com
}

\begin{abstract}
Abstrak
Penelitian ini bertujuan untuk mengetahui pengaruh kualitas pelayanan pendidikan terhadap kepuasan peserta didik di SMA Islam Cikal Harapan Bumi Serpong Damai - Kota Tangerang Selatan. Metode penelitian yang digunakan adalah metode survei dan responden penelitian berjumlah 85 orang. Teknik pengumpulan data menggunakan instrumen angket. Instrumen dikalibrasi dengan menggunakan validitas butir korelasi product moment dan koefisien reliabilitas diuji dengan menggunakan rumus Alpha Cronbach. Uji persyaratan analisis data dilakukan dengan uji normalitas. Sedangkan data penelitian di analisis menggunakan teknik korelasi, determinasi dan regresi linier sederhana. Hasil penelitian menemukan bahwa terdapat hubungan yang signifikan antara kualitas layanan pendidikan terhadap kepuasan peserta didik, dengan konstribusi koefisien determinasi $R^{2}=(0,761)^{2}=0,58=58 \%$ dan persamaan regresi linier $\hat{Y}=-5,904+0,431 X$.
\end{abstract}

Kata kunci: kualitas layanan pendidikan, kepuasan peserta didik.

\begin{abstract}
The objective of this research is to find out the effect of the quality of educational services on student satisfaction in the Islamic High School of Harapan Bumi Serpong Damai - South Tangerang City. The research method used was the survey method and the research respondents were 85 people. The technique of collecting data uses a questionnaire instrument. The instrument was calibrated using product moment correlation item validity and the reliability coefficient was tested using the Cronbach Alpha formula. Test requirements for data analysis were carried out by normality test. While the research data was analyzed using correlation techniques, determination and simple linear regression. The results of the study found that there was a significant relationship between the quality of education services to student satisfaction, with the contribution of the determination coefficient $R^{2}$ $=(0.761)^{2}=0.58=58 \%$ and the linear regression equation $\hat{Y}=-5.904+0.431 X$.
\end{abstract}

Keywords: quality of education services, student satisfaction.

\section{PENDAHULUAN \\ Latar Belakang Masalah}

Kualitas layanan dalam dunia pendidikan merupakan merupakan faktor yang harus diperhatikan. Selain itu kemampuan lembaga pendidikan untuk menghasilkan kualitas lulusan yang kompeten dalam bidangnya serta keberhasilan program kegiatan yang sudah dibuat hendaknya dapat dibuktikan dengan kualitas hasil pendidikan yang dirasakan oleh seluruh peserta didik. Bukti prestasi, evaluasi, sertifikasi kualitas, keberhasilan alumni dalam memperoleh pekerjaan yang layak maupun keberhasilan dlam melanjutkan pendidikan ke janjang pendidikan yang lebih tinggi menjdikan tolak ukur keberhasilan sekolah yang akan diakui oleh masyarakat sebagai pengguna jasa pendidikan. 
Perkembangan ilmu pengetahuan dewasa inipun sangat mempengaruhi proses pendidikan. Oleh karena itu, untuk mengantisipasi perubahan teknologi yang sangat pesat saat ini pemerintah Indonesiapun berusaha untuk membentuk organisasi pendidikan yang bersifat otonom yang tertuang dalam tujuan pendidikan nasional secara makro, sehingga mampu melakukan inovasi dalam pendidikan demi menuju suatu lembaga yang beretika, selalu menggunakan nalar, berkemampuan komunikasi sosial yang positif dan memiliki sumber daya manusia yang sehat dan tangguh. Hal ini sesuai dengan pendapat Mulyasa (2004) "secara mikro pendidikan nasional bertujuan membentuk manusia yang beriman dan bertaqwa kepada Tuhan Yang Maha Esa, beretika (beradab dan berwawasan budaya bangsa Indonesia), memiliki nalar (maju, cakap, cerdas, kreatif, inovatif dan bertanggungjawab), berkemampuan komunikasi sosial (tertib dan sadar hukum, kooperatif dan kompetitif, demokratis), dan berbadan sehat sehingga menjadi manusia mandiri."

Sebagai institusi pendidikan, sekolah dituntut untuk memiliki kemampuan dalam memainkan perannya di era globalisasi saat ini, yang dipadati dengan berbagai fakta perubahan yang sangat cepat dalam berbagai bidang kehidupan, sekaligus dapat mewujudkan tujuan pendidikan sesuai dengan arah kebijakan pemerintah dalam skala makro maupun mikro. Lebih luas lagi peserta didik dipandang sebagai pelanggan eksternal yang dipertimbangkan tidak hanya pada saat ini saja, tetapi juga sebagai asset sekolah di masa mendatang.

Sekolah Cikal Harapan sebagai lembaga pendidikan setingkat menengah (SMU/SMA), tentunya memiliki tugas dan tanggung jawab untuk meningkatkan mutu pendidikannya. Program pendidikannya hendaknya dapat membentuk dan mengembangkan seluruh potensi peserta didik agar memiliki dasar yang kuat untuk berpikir ilmiah melalui proses pembelajaran yang intensif dan sistematis. Tentunya peserta didik bukan hanya diberikan teori dan pengetahuan yang dihafal, serta daya serap sebagai ukuran keberhasilan, tetapi para lulusannya hendaknya memiliki kecakapan dasar untuk mencari dan meneliti sendiri pengetahuan yang berguna melalui proses belajar inquri dan bersifat mandiri. Kecakapan dasar ini haruslah ditumbuhkan melalui programprogram pendidikan, kurikulum dan pembelajaran, serta pendekatan dan proses pengelolaan sekolah.

Menghadapi masalah dalam kaitan de- ngan relevansi kurikulum, pembelajaran, dan manajemen sekolah yang menciptakan proses belajar peserta didik yang mutunya rendah (rote learning), maka proses pembelajaran haruslah dapat menumbuhkan potensi dan kreativitas peserta didik. Bukan pembelajaran yang hanya menyuguhkan teori dan pengetahuan yang dihafal dengan muatan teoritis yang padat. Proses pembelajaran seperti ini sudah menjadi budaya belajar peserta didik di Indonesia, khususnya pada pendidikan dasar dan menengah. Karena sekolah belum mampu menciptakan proses pembelajaran yang nyaman, menarik dan menyenangkan bagi peserta didik untuk belajar optimal, sehingga prestasi belajar peserta didik rendah dan terkesan semakin buruk akhir-akhir ini. (Suryadi, 2010).

Kunci keberhasilan suatu usaha jasa dalam dunia bisnis adalah kepuasan konsumen. Dengan memuaskan konsumen, organisasi dapat meningkatkan tingkat keuntungannya dan mendapatkan pangsa pasar yang lebih luas. Kepuasan konsumen adalah suatu persepsi konsumen terhadap satu jenis pengalaman pelayanan yang dialaminya, Pada dasarnya ada hubungan yang erat antara penentuan kualitas pelayanan dan kepuasan pelanggan. Dalam mengevaluasi hal ini pelanggan akan menggunakan harapannya sebagai standar atau acuan. Umumnya dalam konteks kepuasan pelanggan harapan rnerupakan perkiraan atau keyakinan pelanggan tentang hal yang diterima, Karena kepuasan merupakan faktor penting maka banyak studi dilakukan untuk mengukur kepuasan konsumen.

Sama halnya dalam dunia bisnis, dalam dunia pendidikan mengukur tingkat kepuasan peserta didik terhadap layanan pendidikan menjadi hal yang penting untuk mengetahui seberapa baik layanan yang telah diberikan oleh sekolah. Sekolah sebagai lembaga penyedia jasa pendidikan perlu belajar dan memiliki inisiatif untuk meningkatkan kepuasan pelanggan karena pendidikan merupakan proses sirkuler yang saling mempengaruhi dan berkelanjutan, Oleh karena itu, diperlukan strategi pemasaran jasa pendidikan untuk memenangkan kompetisi antar sekolah serta untuk rneningkatkan akselerasi peningkatan kualitas dan profesionalisme manajemen sekolah, Masyarakat sebagai pelanggan sekolah (peserta didik, orang tua, serta pihak-pihak terkait lainnya) perlu diyakinkan bahwa sekolah yang akan dipilih adalah sekolah yang memberikan pelayanan yang relevan dengan kebutuhan dan tuntutan zaman. Menjamurnya lembaga-lembaga bimbingan belajar dan tempat les atau 
privat menunjukkan bahwa persepsi peserta didik terhadap layanan pendidikan sekolah masih kurang baik serta menunjukkan pula bahwa peserta didik lebih percaya terhadap lembaga bimbingan atau guru privat di luar sekolah lebih mampu membantu meningkatkan prestasi.

SMA Islam Cikal Harapan BSD dipilih sebagai lokasi dan objek penelitian dengan alasan bahwa SMA Islam Cikal Harapan BSD merupakan salah satu SMA swasta yang memiliki otonomi dalam pengelolaan sekolah yang lebih besar dibandingkan dengan sekolah negeri. Selain itu SMA Islam Cikal Harapan BSD adalah salah satu lembaga pendidikan swasta yang terbesar ada di kota Tangerang Selatan. Sejak adanya sekolah-sekolah swasta baru di kota Tangerang Selatan, berdampak kepada berkurangnya jumlah peserta didik. Oleh karena itu, agar dapat tetap bertahan dan bersaing SMAI Cikal Harapan harus dapat memberikan layanan pendidikan yang berkualitas. Tuntutan untuk menyediakan layanan pendidikan yang berkualitas menjadi hal yang harus diperhatikan dalam pengelolaan sekolah karena kualitas akan menjadi ukuran penting bagi loyalitas pengguna langsung yaitu peserta didik.

Berdasarkan latar belakang permasalahan di atas, penulis bermaksud melakukan penelitian untuk mengetahui permasalahan yang dihadapi di Sekolah Menengah Atas Islam Cikal Harapan karena dalam 5 (lima) tahun terakhir ini yang berdampak terhadap berkurangnya jumlah peserta didik yang bersekolah di SMA Islam Cikal Harapan. Permasalahan yang ingin diteliti yaitu berkaitan dengan kualitas layanan pendidikan terhadap kepuasan peserta didik. Sehingga dengan penelitian ini penulis berharap dapat memberikan konstribusi bagi sekolah dalam meningkatkan jumlah peserta didik yang menggunakan layanan pendidikan di sekolah.

\section{Tujuan Penelitian}

Tujuan yang diinginkan dalam penelitian ini adalah untuk menganalisis:

1. Untuk mengetahui dan menganalisis kualitas layanan pendidikan di SMA Islam Cikal Harapan BSD Tangerang Selatan.

2. Untuk mengetahui dan menganalisis kepuasan peserta didik di SMA Islam Cikal Harapan BSD Tangerang Selatan.

3. Untuk mengetahui dan menganalisis pengaruh kualitas layanan pendidikan terhadap kepuasan peserta didik di SMA Islam Cikal Harapan BSD Tangerang Selatan.

\section{Kajian Teori}

\section{Manajemen Jasa}

Definisi pemasaran jasa yang dikutip oleh Kotler dan Keller dalam Fandy Tjiptono (2009;4) "adalah setiap tindakan jasa adalah perbuatan yang dapat ditawarkan oleh suatu pihak kepada pihak lain yang pada dasarnya bersifat intangible (tidak berwujud fisik) dan tidak menghasilkan kepemilikan sesuatu".

Menurut Lovelock dan Gummesson (2011;36) mendefinisikan bahwa service (pelayanan) adalah sebuah bentuk jasa dimana para pelanggan atau konsumen dapat memperoleh manfaat melalui nilai jasa yang diharapkan. Konsep pemasaran jasa secara sederhana sebagai usaha untuk mempertemukan produk atau jasa yang dihasilkan oleh suatu perusahaan dengan calon pelanggan yang akan menggunakan jasa tersebut, oleh karena itu produk dan jasa yang dihasilkan oleh suatu atau perusahaan harus dapat memenuhi kebutuhan dan keinginan pelanggan.

Menurut Payne yang dikutif oleh Ratih Hurriyati (2010:42) bahwa pemasaran jasa merupakan suatu proses mempersepsikan, memahami, menstimulasi dan memenuhi kebutuhan pasar sasaran yang dipilih secara khusus dengan menyalurkan sumber-sumber sebuah organisasi untuk memenuhi kebutuhan tersebut. Dengan demikian, manajemen pemasaran jasa merupakan proses penyelarasan sumbersumber sebuah organisasi terhadap kebutuhan pasar. Pemasaran memberi perhatian pada hubungan timbal balik yang dinamis antara produk dan jasa perusahaan, keinginan dan kebutuhan pelanggan serta kegiatan-kegiatan para pesaing.

Sedangkan Rismiati $(2005 ; 270)$ mendefinisikan pemasaran jasa adalah setiap kegiatan atau manfaat yang ditawarkan oleh satu pihak kepada pihak yang lain dan merupakan barang tidak berwujud (intangible) serta tidak berakibat pada kepemilikan akan sesuatu. Lupiyoadi (2006; 5), mendefinisikan pemasaran jasa adalah setiap tindakan yang ditawarkan oleh salah satu pihak kepada pihak lain yang secara prinsip intangible dan tidak menyebabkan perpindahan kepemilikan apapun.

\section{Kualitas Layanan Pendidikan}

Mutu pendidikan merupakan kebutuhan primer bagi sekolah yang harus ditingkatkan sekolah agar mampu bersaing 
dengan sekolah-sekolah lainnya. Menurut Minarti (2010:327), ada beberapa elemen yang harus diperhatikan bahwa suatu lembaga dikatakan berkualitas yaitu:"

1) Kualitas meliputi usaha memenuhi atau melebihi harapan pelanggan;

2) Kualitas mencakup produk, jasa, manusia, proses. dan lingkungan;

3) Kualitas merupakan kondisi yang selalu berubah (apa yang dianggap berkualitas saat ini mungkin dianggap kurang berkualitas pada saat yang lain);

4) KuaIitas merupakan suatu kondisi dinamis yang berhubungan dengan produk, jasa, manusia, proses, dan lingkungan yang memenuhi atau melebihi harapan."

Menurut Minarti (2011: 250) "mutu atau kualitas layanan pendidikan dapat disimpulkan sebagai derajat keunggulan dalam pengelolaan pendidikan secara efektif dan efisien untuk rnelahirkan keunggulan akademik dan ekstrakurikuler para peserta didik yang dinyatakan lulus untuk satu jenjang pendidikan atau menyelesaikan program pembelajaran tertentu". Mencapai mutu pendidikan diperlukan suatu kegiatan dinamis dan penuh tantangan seiring dengan perubahan zaman. Maka dalarn pendidikan diperlukan adanya upaya perbaikan dan peningkatan mutu sejalan dengan semakin tingginya kebutuhan dan tuntutan kehidupan masyarakat.

Dimensi layanan Pendidikan menurut Minarti (2011: 332-334) dapat dijelaskan sebagai berikut:

1. Bukti fisik (Tangible).

Bukti fisik berupa sarana dan prasarana. "Sarana yang wajib dimiliki meliputi perabot, peralatan pendidikan, media pendidikan, buku dan sumber belajar lainnya, baban habis pakai, serta perlengkapan lain yang diperlukan untuk menunjang proses pembelajaran yang teratur dan berkelanjutan. Sedangkan prasarana yang wajib dimiliki meliputi Lahan, ruang kelas, ruang pimpinan satuan pendidikan, ruang pendidik, ruang tata usaha, ruang perpustakaan, ruang laboratorium, ruang bengkel kerja, ruang unit produksi, ruang kantin, instalasi daya dan jasa, tempat berolahraga, tempat beribadah, tempat bermain, tempat berekreasi, dan ruang/tempat lain yang diperlukan untuk menunjang proses pembelajaran yang teratur dan berkelanjutan."

2. Keandalan (Reliability).

Keandalan adalah kemampuan memberikan pelayanan yang dijanjikan dengan segera atau cepat, akurat, dan memuaskan.

3. Daya tanggap (Responsiveness).

Daya tanggap adalah kemauan/kesediaan para staf untuk membantu para peserta didik dan memberikan pelayanan cepat tanggap.

4. Jaminan (Assurance).

Jaminan mencakup pengetahuan, kompetensi, kesopanan, dan respek terhadap peserta didik. Jaminan memiliki sifat dapat dipercaya, bebas dari bahaya, dan keragu-raguan. Pendidik harus memiliki kualifikasi akademik dan kompetensi sebagai agen pembelajaran, sehat jasmani dan rohani, serta memiliki kemampuan untuk mewujudkan tujuan pendidikan nasional.

5. Empati (Empathy).

Empati adalah "kemudahan dalam melakukan hubungan, komunikasi dengan baik, perhatian pribadi, dan memahami kebutuhan peserta didiknya."

\section{Kepuasan Konsumen}

Dalam dunia bisnis, kepuasan konsumen merupakan salah satu kunci keberhasilan suatu usaha, Hal ini dikarenakan dengan memuaskan konsumen, organisasi dapat meningkatkan tingkat keuntungannya dan meudapatkan pangsa pasar yang lebih luas. Karena kepuasan merupakan faktor penting maka banyak studi dilakukan untuk mengukur kepuasan konsumen.

Kepuasan konsumen menurut Kotler dan Keller (2009:138) adalah "Customer satisfaction is the level o/ a person's fell stale resultating fromcomparing a product's perceived performance (or outcome) in relation to the person's expectation". Kepuasan konsumen adalah tingkat perasaan seseorang sebagai hasil dari perbandingan antara kenyataan dan harapan yang diterima dari sebuah produk atau jasa,

Bagi perusahaan yang berpusat pada pelanggan,kepuasan pelangganmerupakan tujuan dan sarana pemasaran. Perusahaan harus memperhatikan kepuasan pelanggan dengan kemajuan teknologi internet dewasa ini yang menyediakan sarana bagi konsumen untuk menyebarkan berita 
buruk dan berita baik ke seluruh dunia. Bahkan beberapa pelanggan membuat situs sendiri untuk menumpahkan kekesalan dan rasa ketidakpuasannya atas layanan yang mereka rasakan. "Kepuasan konsumen tergantung pula pada kualitas produk dan jasa, Perusahaan yang dapat memuaskan sebagian besar kebutuhan pelanggannya sepanjang waktu disebut perusahaan berkualitas" Kotler dan Keller (2009:144).

Definisi kepuasan dan beberapa uraian di atas secara umum dapat diartikan bahwa antara layanan atau hasil yang diterima itu paling tidak harus sama dengan harapan konsumen. Konsumen mengalami berbagai tingkat kepuasan atau ketidakpuasan setelah mengalami rnasingmasing layanan sesuai dengan sejauh mana harapan terpenuhi atau terlampaui. Pada dasamya konsumen mengharapkan memperoleh produk yang memiliki manfaat pada tingkat harga yang dapat diterima.

Dari uraian di atas, maka kepuasan peserta didik dapat didefinisikan sebagai suatu sikap yang diperlihatkan oleh peserta didik, baik sikap positif maupun sikap negatif atas adanya kesesuaian antara harapan mereka terhadap layanan pendidikan yang diterimanya. Jika layanan pendidikan yang diterima cocok dengan apa yang diharapkan oleh peserta didik maka peserta didik akan merasa puas, dan jika layanan yang diterima tidak sesuai maka peserta didik akan merasa tidak puas. Kepuasan peserta didik sangat tergantung pada persepsi dan harapan mereka terhadap sekolah yang dipengaruhi oleh kebutuhan akan pendidikan dan keinginan untuk dapat berprestasi serta melanjutkan pendidikannya ke jenjang yang lebih tinggi, pengalaman-pengalaman yang dirasakan oleh teman-ternannya atau kakak kelasnya atas kualitas layanan sekolah.

\section{Hipotesis Penelitian}

Penelitian ini menggunakan hipotesis penelitian asosiatif kausal dengan rumusan hipotesis penelitian dan hipotesis statistik sebagai berikut:

$\mathrm{H}_{1}$ : Kualitas layanan pendidikan berpengaruh positif dan signifikan terhadap kepuasan peserta didik di SMA Islam Cikal Harapan Tangerang Selatan.

\section{METODOLOGI PENELITIAN}

Metode penelitian yang digunakan yaitu pendekatan kuantitatif dengan survei untuk mengumpulkan data yang hasil analisisnya akan dihadirkan dalam bentuk angka-angka. Sugiyono (2012) metode penelitian kuantitatif diartikan sebagai metode penelitian yang berlandaskan pada filsafat positivisme, untuk meneliti pada populasi atau sampel tertentu, teknik pengambilan sampel pada umumnya dilakukan secara random, pengumpulan data menggunakan instrumen penelitian, analisis data bersifat kuantitatif atau statistik bertujuan untuk menguji hipotesis yang sudah ditentukan.

\section{Desain Penelitian}

Desain penelitian sebagai bingkai kerja atau cetak biru untuk melaksanakan proyek riset pemasaran Naresh Malhotra, (2009:88). Desain penelitian yang digunakan adalah desain penelitian kausal, riset kausal menurut Naresh Malhotra (2009:100) merupakan satu jenis riset konklusif yang tujuan utamanya adalah mendapatkan bukti mengenai hubungan sebab akibat. Riset kausal disebut sebagai riset konklusif dikarenakan memuat kesimpulan akhir (conclusif) dari hasil temuan. Selanjutnya pada penelitian ini variabel bebas mempengaruhi variabel terikat. Hal ini dikarenakan penelitian ini bertujuan untuk mengetahui pengaruh antara variabel bebas (X) terhadap variabel terikat $(\mathrm{Y})$ yang kemudian akan diambil sebuah kesimpulan.

\section{Operasional Variabel}

Dalam penelitian ini operasional variabel diidentifikasikan sebagai berikut:

\section{Operasional Variabel Kualitas Layanan}

\begin{tabular}{|c|c|c|c|}
\hline No & Variabel & Indikator & Tema Pernyataan/pertanyaan \\
\hline \multirow[t]{3}{*}{1.} & \multirow[t]{3}{*}{$\begin{array}{l}\text { Kualitas } \\
\text { Layanan (X) }\end{array}$} & $\begin{array}{l}\text { 1. Bukti fisik } \\
\text { (Tangible) }\end{array}$ & $\begin{array}{l}\text { 1. Fasilitas belajar yang lengkap } \\
\text { 2. Lokasi terjangkau dan tempat } \\
\text { parkir yang luas } \\
\text { 3. Kebersihan sekolah yang terjaga } \\
\text { 4. Ruang kelas yang nyaman }\end{array}$ \\
\hline & & $\begin{array}{l}\text { 2. Keandalan } \\
\text { (Reability) }\end{array}$ & $\begin{array}{l}\text { 1. Sekolah menyediakan kurikulum } \\
\text { sesuai dengan yang dijanjikan } \\
\text { 2. Sekolah menjamin mutu pembe- } \\
\text { lajaran yang dapat diandalkan } \\
\text { 3. Pengadminstrasian sekolah } \\
\text { dalam menyimpan catatan atau } \\
\text { dokumen tanpa kesalahan } \\
\text { 4. Waktu sekolah yang optimal } \\
\text { dalam pembelajaran }\end{array}$ \\
\hline & & $\begin{array}{l}\text { 3. Daya Tanggap } \\
\text { (Responsiveness) }\end{array}$ & $\begin{array}{l}\text { 1. Menginformasikan tentang } \\
\text { kepastian waktu } \\
\text { 2. Layanan cepat bagi siswa } \\
\text { 3. Kesediaan untuk membantu } \\
\text { pelanggan } \\
\text { 4. Kesiapan untuk merespon } \\
\text { permintaan pelanggan }\end{array}$ \\
\hline
\end{tabular}




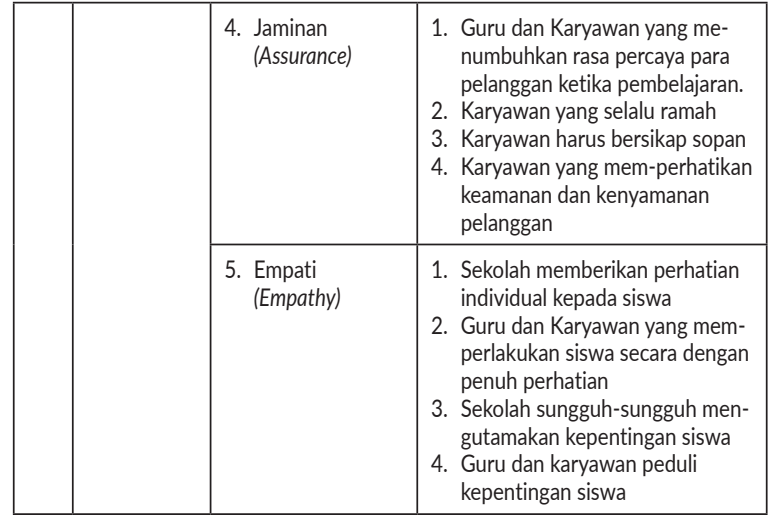

\section{Operasional Variabel Kepuasan Peserta Didik}

Tabel 1.2. Operasional Variabel Kepuasan Peserta Didik

\begin{tabular}{|c|c|c|c|}
\hline No & Variabel & Indikator & Tema Pernyataan/pertanyaan \\
\hline \multirow[t]{3}{*}{1.} & \multirow[t]{3}{*}{$\begin{array}{l}\text { Kepuasan } \\
\text { Peserta } \\
\text { Didik (Y) }\end{array}$} & 1. Nilai & $\begin{array}{l}\text { 1. Penilaian yang dilakukan guru } \\
\text { belum mampu menggambarkan } \\
\text { dan atau mengukur kemam- } \\
\text { puan belajar saya. } \\
\text { 2. Metode pembelajaran guru } \\
\text { menyulitkan siswa dalam mem- } \\
\text { pelajari dan menguasai materi } \\
\text { pelajaran. } \\
\text { 3. Fasilitas yang diberikan sekolah } \\
\text { sangat memuaskan }\end{array}$ \\
\hline & & 2. Layanan & $\begin{array}{l}\text { 1. Layanan yang diberikan sekolah } \\
\text { selama proses pembelajaran } \\
\text { tidak sesuai dengan yang dijanji- } \\
\text { kan. } \\
\text { 2. Fasilitas yang disediakan seko- } \\
\text { lah dapat memenuhi kebu- } \\
\text { tuhan yang diinginkan seluruh } \\
\text { siswa } \\
\text { 3. Lingkungan sekolah mendukung } \\
\text { tercapainya tujuan pembelaja- } \\
\text { ran yang diinginkan siswa }\end{array}$ \\
\hline & & $\begin{array}{l}\text { 3. Kesesuaian } \\
\text { Harapan }\end{array}$ & $\begin{array}{l}\text { 1. Proses pembelajaran di sekolah } \\
\text { memberikan belum memberikan } \\
\text { manfaat sesuai harapkan yang } \\
\text { saya inginkan. } \\
\text { 2. Biaya pendidikan di sekolah } \\
\text { sesuai dengan manfaat yang } \\
\text { saya harapkan. } \\
\text { 3. Saya merasa puas terhadap } \\
\text { kualitas layanan yang diberikan } \\
\text { oleh sekolah. }\end{array}$ \\
\hline
\end{tabular}

Dalam penelitianini, penelitimenggunakan skala Likert 1 sampai 4, sehingga responden dapat memberikan masukan atas penggunaan jasa pendidikan tersebut. Setuju dan tidak setuju terhadap suatu pernyataan, sehingga setiap responden diminta untuk menjawab suatu pernyataan dengan empat alternatif, mulai dari tingkat sangat tidak setuju sampai sangat setuju. Setiap jawaban dari responden di beri skor 1 sampai 4 .

Sugiyono (2012:132) Skala Likert adalah skala yang digunakan untuk mengukur sikap, pendapat dan persepsi seseorang atau sekelompok orang tentang fenomena sosial. Menggunakan skala Likert, variabel yang diukur akan dipaparkan menjadi indikator variabel dan kemudian indikator tersebut digunakan sebagai titik tolak untuk menyusun item-item instrumen yang dapat berupa pertanyaan atau pernyataan, empat pilihan jawaban dengan menyatakan setuju atau tidak setuju terhadap subyek, obyek atau suatu peristiwa. Skala likert ini menggunakan empat angka penilaian, yaitu:

a) Jawaban sangat setuju mendapat nilai 4

b) Jawaban setuju mendapat nilai 3

c) Jawaban tidak setuju mendapat nilai 2

d) Jawaban sangat tidak setuju mendapat nilai 1

Berikut tabel skala likert untuk variabel bebas dan terikat dalam penelitian ini:

\begin{tabular}{|c|c|c|}
\hline No & Alternatif Jawaban & Bobot Nilai \\
\hline 1 & SS (Sangat Setuju) & 4 \\
\hline 2 & S (Setuju) & 3 \\
\hline 3 & TS (Tidak Setuju) & 2 \\
\hline 4 & STS (Sangat Tidak Setuju) & 1 \\
\hline
\end{tabular}

Sedangkan kriteria rentang nilai jawaban responden bobot jawaban responden dapat dihitung dengan rumus:

Rentang nilai $=$

$\frac{(\text { skor tertinggi-skor terendah })}{4}=\frac{4-1}{4}=0,75$

Rentangan dapat dilihat pada tabel berikut.

Tabel 1.4. Kriteria Jawaban Responden

\begin{tabular}{|c|c|c|}
\hline No & Rentang Nilai & Kriteria \\
\hline 1 & $1,00-1,75$ & Sangat Kurang \\
\hline 2 & $1,76-2,50$ & Kurang \\
\hline 3 & $2,51-3,25$ & Baik \\
\hline 4 & $3,25-4,00$ & Sangat Baik \\
\hline
\end{tabular}

\section{Kisi-kisi Instrumen Variabel Penelitian \\ Kisi-kisi instrumen variabel kualitas layanan.}

Tabel 1.5. Kisi-kisi Instrumen Variabel Kualitas Layanan (X)

\begin{tabular}{|c|l|c|c|c|}
\multirow{2}{*}{ No } & \multirow{2}{*}{ Indikator } & \multicolumn{2}{|c|}{ Butir Pernyataan } & \multirow{2}{*}{ Jumlah } \\
\cline { 3 - 4 } & & Positif & Negatif & \\
\hline 1 & Bukti Fisik (Tangible) & $4,5,6,7,8$ & $1,2,3$ & 8 \\
\hline 2 & Keandalan (Reliability) & 11,12 & 9,10 & 4 \\
\hline 3 & Daya Tanggap (Responsiveness) & 14,15 & 13 & 3 \\
\hline 4 & Jaminan (Assurance) & $18,19,20$ & 16,17 & 5 \\
\hline 5 & Empati (Empathy) & 23,24 & 21,22 & 4 \\
\hline \multicolumn{2}{|c}{ Jumlah } & \\
\hline
\end{tabular}


Kisi-kisi instrumen variabel kepuasan peserta didik.

\begin{tabular}{|c|c|c|c|c|}
\hline \multicolumn{5}{|c|}{ Tabel 1.6. Kisi-kisi Instrumen Variabel Kepuasan Peserta Didik (Y) } \\
\hline \multirow{2}{*}{ No } & \multirow{2}{*}{ Indikator } & \multicolumn{2}{|c|}{ Butir Pernyataan } & \multirow{2}{*}{ Jumlah } \\
\hline & & Positif & Negatif & \\
\hline 1 & Nilai & 3 & 1,2 & 3 \\
\hline 2 & Layanan & 5,6 & 4 & 3 \\
\hline 3 & Kesesuaian Harapan & 8,9 & 7 & 3 \\
\hline \multicolumn{4}{|c|}{ Jumlah } & 9 \\
\hline
\end{tabular}

\section{Populasi dan Sampel}

Populasi merupakan wilayah generalisasi yang terdiri atas: obyek atau subyek yang mempunyai kualitas dan karakteristik tertentu yang ditetapkan oleh peneliti untuk dipelajari dan kemudian ditarik kesimpulannya. Sugiyono (2012:115). Populasi yang akan di teliti disini adalah peserta didik di Sekolah Menengah Atas Islam Cikal Harapan yang berjumlah 85 peserta didik.

Penelitian ini dilakukan dengan cara mengambil keseluruhan populasi dikarenakan jumlah peserta didik yang hanya 85 orang sehingga memudahkan peneliti untuk meneliti keseluruhan peserta didik untuk dijadikan objek penelitian dan sampel. Maka penelitian dapat dilakukan dengan metode sensus terhadap semua peserta didik. Artinya penelitian ini melibatkan seluruh populasi sehingga sampel sama dengan populasi (metode sampel jenuh).

\section{Rancangan Analisis}

1. Uji Validitas Masing-masing Variabel

Menguji validitas konstruksi, dapat menggunakan pendapat dari ahli (judgment experts), Setelah instrumen dikontruksi tentang aspek-aspek yang akan diukur dengan berlandaskan teori tertentu. Cara yang dilakukan adalah dengan analisis item, dimana setiap nilai total seluruh butir pertanyaan untuk suatu variabel dengan menggunakan rumus korelasi Product Moment. (Sugiyono: 2012,177). Pengujian validitas intrumen menggunakan rumus korelasi pearson product moment, dengan ketentuan instrumen penelitian dikatakan valid jika $\mathrm{r}_{\text {hitung }}>\mathrm{r}_{\text {tabẹ }}$.

2. Uji Reliabilitas Masing-masing Variabel

Uji reliabilitas digunakan untuk mengetahui konsistensi alat ukur yang digunakan dapat diandalkan dan tetap konsisten jika pengukuran tersebut diulang. Kuesioner yang reliabel adalah kuesioner yang apabila dicobakan secara berulang-ulang kepada kelompok yang sama akan menghasilkan data yang relatif konsisten. Uji reliabilitas menggunakan nilai Alpha Coanbach dengan ketentuan instrument dikatakan reliabel jika nilai Alpha Croanbach $\left(\mathrm{r}_{\text {hitung }}\right)>$ 0,60 .

\section{Uji Normalitas}

Pengujian normalitas adalah pengujian tentang kenormalan distribusi data. Data terdistribusi normal apabila data memusat pada nilai rata-rata dan median. Pengujian normalitas menggunakan One-sample Kolmogorov-Smirnov Test dengan SPSS 21.0 for windows. Jika nilai Asymp Sig > 0,05 maka data berdistribusi normal.

\section{Analisis Regresi Linier}

Analisis regresi linier digunakan untuk mencari dan membuktikan pengaruh dari variabel kualitas layanan pendidikan terhadap variabel kepuasan peserta didik. Bentuk umum persamaan regresi liniernya $\hat{Y}=a+b X$. Dimana $\mathrm{X}$ dan Y merupakan variabel yang diteliti. Sedangkan a dan b merupakan konstanta dan koefisien arah regresinya.

\section{Uji Koefisien Determinasi (Uji $\mathbf{R}^{\mathbf{2}}$ )}

Uji determinasi berguna untuk menginformasikan baik atau tidaknya model regresi yang terestimasi, untuk mengukur seberapa dekatkah garis regresi yang terestimasi dengan data sesungguhnya. Nilai koefisien determinasi $\left(\mathrm{R}^{2}\right)$ ini mencerminkan seberapa besar variasi dari variabel terikat $Y$ dapat diterangkan oleh variabel bebas X. Bila nilai koefisien determinasi sama dengan $\mathrm{O}\left(\mathrm{R}^{2}=0\right)$, artinya variasi dari $\mathrm{Y}$ tidak dapat diterangkan oleh variabel $\mathrm{X}$.

\section{HASIL PENELITIAN}

Deskripsi Data Penelitian

1. Deskripsi Variabel Kualitas Layanan.

Variabel kualitas layanan memiliki beberapa indikator yang dituangkan seluruhnya terhadap 24 pernyataan. Berikut analisis deskriptif kategori terhadap 24 item pertanyaan pada variabel pemimpin.

Tabel 1.7. Persepsi Responden Mengenai Variabel Kualitas Layanan

\begin{tabular}{|c|c|c|c|c|c|c|c|c|c|c|}
\hline No & $\begin{array}{c}\text { Per- } \\
\text { nyataan/ } \\
\text { Instru- } \\
\text { men }\end{array}$ & SS & S & TS & STS & Jumlan & $\begin{array}{c}\text { Total } \\
\text { Skor }\end{array}$ & $\begin{array}{c}\text { Rata- } \\
\text { rata }\end{array}$ & Ket \\
\hline A & \multicolumn{3}{|c|}{ Bukti Fisik } \\
\hline 1 & Inst-1 & 17 & 49 & 17 & 2 & 85 & 251 & 2.95 & Baik \\
\hline 2 & Inst-2 & 11 & 35 & 36 & 3 & 85 & 224 & 2.64 & Baik \\
\hline 3 & Inst-3 & 42 & 42 & 1 & 0 & 85 & 296 & 3.48 & Baik Sekali \\
\hline 4 & Inst-4 & 33 & 40 & 11 & 1 & 85 & 275 & 3.24 & Baik \\
\hline 5 & Inst-5 & 37 & 39 & 8 & 1 & 85 & 282 & 3.32 & BaikSekali \\
\hline 6 & Inst-6 & 10 & 39 & 33 & 3 & 85 & 226 & 2.66 & Baik \\
\hline
\end{tabular}




\begin{tabular}{|c|c|c|c|c|c|c|c|c|c|}
\hline 7 & Inst-7 & 27 & 51 & 7 & 0 & 85 & 275 & 3.24 & Baik \\
\hline 8 & Inst-8 & 16 & 55 & 14 & 0 & 85 & 257 & 3.02 & Baik \\
\hline \multicolumn{2}{|c|}{ Jumlah_1 } & 193 & 350 & 127 & 10 & 680 & 2086 & 3.07 & Baik \\
\hline$B$ & \multicolumn{9}{|c|}{ Keandalan } \\
\hline 9 & Inst-9 & 32 & 44 & 9 & 0 & 85 & 278 & 3.27 & Baik Sekali \\
\hline 10 & Inst-10 & 36 & 36 & 13 & 0 & 85 & 278 & 3.27 & Baik Sekali \\
\hline 11 & Inst-11 & 23 & 50 & 11 & 1 & 85 & 265 & 3.12 & Baik \\
\hline 12 & Inst-12 & 20 & 58 & 7 & 0 & 85 & 268 & 3.15 & Baik \\
\hline \multicolumn{2}{|c|}{ Jumlah_2 } & 111 & 188 & 40 & 1 & 340 & 1089 & 3.20 & Baik \\
\hline$c$ & \multicolumn{9}{|c|}{ Daya Tanggap } \\
\hline 13 & Inst-13 & 12 & 45 & 27 & 1 & 85 & 238 & 2.80 & Baik \\
\hline 14 & Inst-14 & 19 & 46 & 19 & 1 & 85 & 253 & 2.98 & Baik \\
\hline 15 & Inst-15 & 15 & 46 & 22 & 2 & 85 & 244 & 2.87 & Baik \\
\hline \multicolumn{2}{|c|}{ Jumlah_3 } & 46 & 137 & 68 & 4 & 255 & 735 & 2.88 & Baik \\
\hline D & \multicolumn{9}{|l|}{ Jaminan } \\
\hline 16 & Inst-16 & 44 & 31 & 9 & 1 & 85 & 288 & 3.39 & BaikSekali \\
\hline 17 & Inst-17 & 16 & 51 & 18 & 0 & 85 & 253 & 2.98 & Baik \\
\hline 18 & Inst-18 & 19 & 50 & 16 & 0 & 85 & 258 & 3.04 & Baik \\
\hline 19 & Inst-19 & 15 & 50 & 18 & 2 & 85 & 248 & 2.92 & Baik \\
\hline \multicolumn{2}{|c|}{ Jumlah_4 } & 94 & 182 & 61 & 3 & 340 & 1047 & 3.08 & Baik \\
\hline $\mathrm{E}$ & \multicolumn{9}{|l|}{ Empati } \\
\hline 20 & Inst-20 & 19 & 45 & 19 & 2 & 85 & 251 & 2.95 & Baik \\
\hline 21 & Inst-21 & 16 & 51 & 18 & 0 & 85 & 253 & 2.98 & Baik \\
\hline 22 & Inst-22 & 15 & 58 & 11 & 1 & 85 & 257 & 3.02 & Baik \\
\hline 23 & Inst-23 & 15 & 45 & 25 & 0 & 85 & 245 & 2.88 & Baik \\
\hline 24 & Inst-24 & 12 & 44 & 27 & 2 & 85 & 236 & 2.78 & Baik \\
\hline \multicolumn{2}{|c|}{ Jumlah_5 } & 77 & 243 & 100 & 5 & 425 & 1242 & 2.92 & Baik \\
\hline \multicolumn{2}{|c|}{ Total } & 521 & 1100 & 396 & 23 & 2040 & 6199 & 3.04 & Baik \\
\hline
\end{tabular}

Tabel 1.7 di atas merupakan hasil dari persepsi 85 responden terhadap 24 item pertanyaan pada variabel kualitas layanan, diperoleh hasil dari tertinggi sampai terendah sebagai berikut:

1) Indikatorkeandalan (reability) dengan skor rata-rata 3,20 pada rentang 2,513,25 artinya tanggapan responden terhadap indikator keandalan sekolah sudah baik.

2) Indikator jaminan (assurance) dengan skor rata-rata 3,08 pada rentang 2,513,25 artinya tanggapan responden terhadap indikator jaminan sudah baik.

3) Indikator bukti fisik dengan skor rata-rata 3,07 pada rentang 2,51-3,25 artinya tanggapan responden terhadap indikator bukti fisik sekolah sudah baik.

4) Indikator empati dengan skor ratarata 3,04 pada rentang 2,51-3,25 artinya tanggapan responden terhadap indikator empati sudah baik.

5) Indikator daya tanggap (respon- siveness) dengan skor rata-rata 2,88 pada rentang 2,51-3,25 artinya tanggapan responden terhadap indikator daya tanggap sudah baik.

Berdasarkan jawaban keseluruhan responden rata-rata jawaban responden tentang variabel kualitas layanan yaitu 3,04 direntang 2,51-3,25, hal ini menunjukkan respon responden terhadap pernyataan yang diajukan untuk variabel kualitas layanan secara keseluruhan lebih memilih jawaban baik/setuju. Adapun indikator tertinggi yaitu pada keandalan (reability) dengan rata-rata nilai skor jawaban responden 3,20 artinya kurikulum yang diberikan sekolah sudah sangat baik. Sedangkan indikator yang perlu ditingkatkan kualitasnya yaitu indikator daya tanggap (responsiveness) karena memiliki rata-rata skor jawaban terendah sebesar 2,88.

2. Deskripsi Variabel Kepuasan Peserta Didik.

Variabel kepuasan peserta didik memiliki beberapa indikator yang dituangkan seluruhnya terhadap 9 pernyataan. Berikut analisis deskriptif kategori terhadap 9 item pertnyataan pada variabel kepuasan peserta didik.

\begin{tabular}{|c|c|c|c|c|c|c|c|c|c|}
\hline \multicolumn{10}{|c|}{ Tabel 1.8. Persepsi Responden terhadap Kepuasan Peserta Didik } \\
\hline \multirow[b]{2}{*}{ № } & & \multicolumn{4}{|c|}{ Jawaban Responden } & \multirow[b]{2}{*}{ Jumlah } & \multirow[b]{2}{*}{$\begin{array}{l}\text { Total } \\
\text { Skor }\end{array}$} & \multirow[b]{2}{*}{$\begin{array}{l}\text { Rata- } \\
\text { rata }\end{array}$} & \multirow[b]{2}{*}{ Ket } \\
\hline & $\begin{array}{l}\text { nyataan/ } \\
\text { Instru- } \\
\text { men }\end{array}$ & sS & $\mathrm{s}$ & TS & STS & & & & \\
\hline A & \multicolumn{9}{|l|}{ Nilai } \\
\hline 1 & Inst-1 & 9 & 60 & 15 & 1 & 85 & 247 & 2.91 & Baik \\
\hline 2 & Inst-2 & 10 & 51 & 23 & 1 & 85 & 240 & 2.82 & Baik \\
\hline 3 & Inst-3 & 14 & 41 & 25 & 5 & 85 & 234 & 2.75 & Baik \\
\hline \multicolumn{2}{|c|}{ Jumlah_1 } & 33 & 152 & 63 & 7 & 255 & 721 & 2.83 & Baik \\
\hline B & \multicolumn{9}{|l|}{ Layanan } \\
\hline 4 & Inst-4 & 12 & 52 & 21 & 0 & 85 & 246 & 2.89 & Baik \\
\hline 5 & Inst-5 & 12 & 43 & 26 & 4 & 85 & 233 & 2.74 & Baik \\
\hline 6 & Inst-6 & 13 & 48 & 22 & 2 & 85 & 242 & 2.85 & Baik \\
\hline \multicolumn{2}{|c|}{ Jumlą_2 } & 37 & 143 & 69 & 6 & 255 & 721 & 2.83 & Baik \\
\hline c & \multicolumn{9}{|c|}{ Kesesuaian Layanan } \\
\hline 7 & Inst-7 & 11 & 55 & 18 & 1 & 85 & 246 & 2.89 & Baik \\
\hline 8 & Inst-8 & 11 & 48 & 20 & 6 & 85 & 234 & 2.75 & Baik \\
\hline 9 & Inst-9 & 11 & 41 & 29 & 4 & 85 & 229 & 2.69 & Baik \\
\hline \multicolumn{2}{|c|}{ Jumlą_3 } & 33 & 144 & 67 & 11 & 255 & 709 & 2.78 & Baik \\
\hline \multicolumn{2}{|r|}{ Total } & 103 & 439 & 199 & 24 & 765 & 2151 & 2.81 & Baik \\
\hline & & & & & & & \multicolumn{3}{|c|}{ Sumber: Pengolahan data (2018 } \\
\hline
\end{tabular}

Tabel 1.8. di atas merupakan hasil dari persepsi 85 responden terhadap 9 item pernyataan pada variabel citra sekolah, dapat dilihat bahwa dari hasil pengolahan data di atas diperoleh data: 
1) Indikator nilai dengan skor rata-rata 2,83 pada rentang $2,51-3,25$ artinya tanggapan responden terhadap indikator nilai sudah baik.

2) Indikator layanan dengan skor ratarata 2,83 pada rentang 2,51-3,25 artinya tanggapan responden terhadap indikator layanan sudah baik.

3) Indikator kesesuaian layanan dengan skor rata-rata 2,78 pada rentang $2,5^{-}$ 3,25 artinya tanggapan responden terhadap indikator kesesuaian layanan sudah baik.

Berdasarkan jawaban keseluruhan rata-rata jawaban responden tentang variabel kepuasan peserta didik yaitu skor 2,81 berada di rentang 2,51-3,25, hal ini menunjukkan respon dari responden terhadap pernyataan yang diajukan untuk variabel kepuasan peserta didik secara keseluruhan rata-rata memilih jawaban setuju/baik. Indikator kepuasan peserta didik yang harus dipertahankan yaitu pada nilai dan keadalan dengan rata-rata nilai skor jawaban tertinggi responden 2,83 . Sedangkan indikator yang perlu ditingkatkan yaitu indikator kesesuaian layanan karena memiliki rata-rata skor jawaban terendah sebesar 2,78.

\section{Uji Validitas Variabel \\ Layanan Pendidikan}

Hasil uji validitas menggunakan rumus korelasi product moment dan membandingkan dengan rtabel pada taraf siginfikansi sebsar 5\% diperoleh rtabel sebesar 0,220. Hasil pengujian instrumen kuesiner no 1 untuk setiap variabel diperoleh nilai:

1. Uji Validitas Variabel Layanan Pendidikan

\begin{tabular}{|c|c|c|c|c|}
\hline \multicolumn{2}{|c|}{ Variabel } & $r_{\text {hitung }}$ & $r_{\text {tabel }}$ & Keterangan \\
\hline \multirow{14}{*}{$\begin{array}{c}\text { Kualitas } \\
\text { Layanan } \\
\left(X_{1}\right)\end{array}$} & Instr1 & $.394^{* *}$ & 0,220 & Valid \\
\hline & Instr2 & $.677^{* *}$ & 0,220 & Valid \\
\hline & Instr3 & $.363^{* *}$ & 0,220 & Valid \\
\hline & Instr4 & $.358^{* *}$ & 0,220 & Valid \\
\hline & Instr5 & $.523^{* *}$ & 0,220 & Valid \\
\hline & Instr6 & $.501^{* *}$ & 0,220 & Valid \\
\hline & Instr7 & $.625^{* *}$ & 0,220 & Valid \\
\hline & Instr8 & $.576^{* *}$ & 0,220 & Valid \\
\hline & Instr9 & $.542^{* *}$ & 0,220 & Valid \\
\hline & Instr10 & $.521^{* *}$ & 0,220 & Valid \\
\hline & Instr11 & $.492^{* *}$ & 0,220 & Valid \\
\hline & Instr12 & $.505^{* *}$ & 0,220 & Valid \\
\hline & Instr13 & $.596^{* *}$ & 0,220 & Valid \\
\hline & Instr14 & $.627^{* *}$ & 0,220 & Valid \\
\hline
\end{tabular}

\begin{tabular}{|c|c|c|c|c|}
\hline \multirow{4}{*}{} & Instr15 & $.637^{* *}$ & 0,220 & Valid \\
\cline { 2 - 5 } & Instr16 & $.433^{* *}$ & 0,220 & Valid \\
\cline { 2 - 5 } & Instr17 & $.528^{* *}$ & 0,220 & Valid \\
\cline { 2 - 5 } & Instr18 & $.693^{* *}$ & 0,220 & Valid \\
\cline { 2 - 5 } $\begin{array}{c}\text { Kualitas } \\
\text { Layanan } \\
\left(\mathrm{X}_{1}\right)\end{array}$ & Instr19 & $.621^{* *}$ & 0,220 & Valid \\
\cline { 2 - 5 } & Instr20 & $.509^{* *}$ & 0,220 & Valid \\
\cline { 2 - 5 } & Instr21 & $.622^{* *}$ & 0,220 & Valid \\
\cline { 2 - 5 } & Instr22 & $.674^{* *}$ & 0,220 & Valid \\
\cline { 2 - 5 } & Instr23 & $.448^{* *}$ & 0,220 & Valid \\
\cline { 2 - 5 } & Instr24 & $.569^{* *}$ & 0,220 & Valid \\
\hline \multicolumn{4}{|c}{} & \multicolumn{3}{|c}{ Sumber: Pengolahan data (2018) } \\
\hline \multicolumn{4}{|c|}{} & \multicolumn{3}{|c}{}
\end{tabular}

Dari tabel di atas, dapat disimpulkan bahwa seluruh instrumen dari variabel kualitas layanan, memiliki nilai $\mathrm{r}_{\text {hitum }}$ lebih besar $\mathrm{r}_{\text {tabel }}(0,220)$, dengan demikian seluruh butir pernyataan kuesioner dinyatakan valid.

2. Uji Validitas Variabel Kepuasan Peserta Didik

\begin{tabular}{|c|c|c|c|c|}
\hline \multicolumn{5}{|c|}{ Tabel 1.10. Uji Validitas Butir Pernyataan Variabel Kepuasan Peserta Didik } \\
\hline \multicolumn{2}{|c|}{ Variabel } & $r_{\text {hitung }}$ & $r_{\text {tabel }}$ & Keterangan \\
\hline \multirow{9}{*}{$\begin{array}{c}\text { Kepuasan } \\
\text { Peserta } \\
\text { Didik } \\
\text { (Y) }\end{array}$} & Instr1 & $.541^{* *}$ & 0,220 & Valid \\
\hline & Instr2 & $.644^{* *}$ & 0,220 & Valid \\
\hline & Instr3 & $.853^{* *}$ & 0,220 & Valid \\
\hline & Instr4 & $.664^{* *}$ & 0,220 & Valid \\
\hline & Instr5 & $.789^{* *}$ & 0,220 & Valid \\
\hline & Instr6 & $.739^{* *}$ & 0,220 & Valid \\
\hline & Instr7 & $.781^{* *}$ & 0,220 & Valid \\
\hline & Instr8 & $.756^{* *}$ & 0,220 & Valid \\
\hline & Instr9 & $.819^{* *}$ & 0,220 & Valid \\
\hline & & & er: Peng & n data (2018) \\
\hline
\end{tabular}

Dari tabel di atas, dapat disimpulkan bahwa seluruh instrumen dari kepuasan peserta didik memiliki nilai $\mathrm{r}_{\text {hitung }}$ lebih besar $\mathrm{r}_{\text {tabel }}(0,220)$, dengan demikian seluruh butir pernyataan kuesioner dinyatakan valid.

\section{Uji Reliabilitas}

Uji Reliabilitas digunakan untuk menunjukkan sejauh mana suatu instrumen dapat memberikan hasil pengukuran yang konsisten apabila pengukuran diulang dua kali atau lebih. Metode yang digunakan dalam analisis reliabilitas ini adalah metode Alpha-Cronbach. Pengambilan keputusan reliabilitas suatu variabel ditentukan dengan membandingkan nilai alpha dengan nilai 0,6 . Apabila nilai alpha lebih besar dari o,6 maka variabel yang diteliti adalah reliabel. Adapun hasil analisis uji reliabilitas yang diteliti dalam penelitian ini dapat dilihat tabel 1.11 : 


\begin{tabular}{|l|c|c|c|}
\hline \multicolumn{5}{|c|}{ Tabel 1.11. Uji Reliabilitas } \\
\hline \multicolumn{1}{|c|}{ Variabel } & Cronbach's Alpha & N of Items & Keterangan \\
\hline $\begin{array}{l}\text { Kualitas Layanan } \\
(X)\end{array}$ & 0,895 & 24 & Reliabel \\
\hline $\begin{array}{l}\text { Kepuasan peserta } \\
\text { didik (Y) }\end{array}$ & 0,894 & 9 & Reliabel \\
\hline \multicolumn{4}{|c|}{ Sumber: Pengolahan data (2018) } \\
\hline
\end{tabular}

Berdasarkan tabel di atas, karena nilai Alpha-Cronbach semua variabel > 0,6 maka seluruh variabel yang diteliti adalah reliabel.

\section{Uji Normalitas}

Tujuan uji normalitas untuk menguji apakah model regresi, variabel dependen dan independen keduanya memiliki distribusi normal atau tidak. Hasil uji normalitas dapat dilihat dari nilai Asym.sig pata tabel One Sample Kolmogrov Smirnov Test:

\begin{tabular}{|c|c|c|}
\hline \multicolumn{3}{|c|}{ Tabel 1.12. Uji Kolmogorov-Smirnov } \\
\hline \multicolumn{3}{|c|}{ One-Sample Kolmogorov-Smirnov Test } \\
\hline & & $\begin{array}{l}\text { Unstandardized } \\
\text { Residual }\end{array}$ \\
\hline \multicolumn{2}{|l|}{$\mathrm{N}$} & 85 \\
\hline \multirow{3}{*}{ Normal Parameters ${ }^{\mathrm{a}, \mathrm{B}}$} & Mean & .0000000 \\
\hline & Std. Deviation & 2.98946383 \\
\hline & Absolute & .080 \\
\hline \multirow{2}{*}{ Most Extreme Differences } & Positive & .037 \\
\hline & Negative & -.080 \\
\hline \multicolumn{2}{|l|}{ Kolmogorov-Smirnov Z } & .733 \\
\hline \multicolumn{2}{|l|}{ Asymp. Sig. (2-Tailed) } & .655 \\
\hline \multicolumn{3}{|c|}{$\begin{array}{l}\text { A. Test Distribution Is Normal. } \\
\text { B. Calculated From Data. }\end{array}$} \\
\hline \multicolumn{3}{|c|}{ Sumber: Data diolah (2018) } \\
\hline
\end{tabular}

Dari uji Kolmogorov-Smirnov diperoleh angka sig. 0,655 lebih besar dari 0.05, dengan demikian sebaran data berdistribusi normal. Sehingga bisa dikatakan dalam hal ini datadata tersebut baik untuk dianalisis lebih lanjut.

\section{Regresi Linier Sederhana}

Tabel 1.13. Output Analisis Regresi Linier Sederhana

\begin{tabular}{|c|c|c|c|c|c|c|}
\hline \multicolumn{7}{|c|}{ Coefficients $^{\mathrm{a}}$} \\
\hline \multirow{2}{*}{\multicolumn{2}{|c|}{ Model }} & \multicolumn{2}{|c|}{$\begin{array}{l}\text { Unstandardized } \\
\text { Coefficients }\end{array}$} & \multirow{2}{*}{$\begin{array}{c}\text { Standardized } \\
\text { Coefficients } \\
\text { Beta }\end{array}$} & \multirow[b]{2}{*}{$t$} & \multirow[b]{2}{*}{ Sig. } \\
\hline & & B & $\begin{array}{l}\text { Std. } \\
\text { Error }\end{array}$ & & & \\
\hline \multirow[t]{2}{*}{1} & (Constant) & -5.904 & 2.935 & & -2.011 & .048 \\
\hline & Kualitas Layanan $\left(X_{1}\right)$ & .431 & .040 & .761 & 10.699 & .000 \\
\hline \multicolumn{7}{|c|}{ a. Dependent Variable: Kepuasan Konsumen (Y) } \\
\hline \multicolumn{7}{|c|}{ Sumber: Data diolah (2018) } \\
\hline
\end{tabular}

Dari tabel 1.6. diperoleh model regresi linier $\mathrm{Y}=-5,904+0,431 \mathrm{X}$. a. Angka konstanta -5,904 menyatakan apabila tidak ada upaya yang baik terhadap kualitas layanan pendidikan maka kepuasan peserta didik bernilai negatif.

b. Koefisien arah kualitas layanan pendidikan bernilai positif 0,431 , artinya apabila variabel kualitas layanan pendidikan ditingkatkan 1 satuan, maka kepuasan peserta didik akan mengalami kenaikan sebesar 0,431 .

\section{Uji Hipotesis}

Hipotesis yang akan diuji pada penelitian ini adalah :

$\mathrm{H}_{0}: \beta 1=\mathrm{o}$ artinya variabel kualitas layanan pendidikan tidak memberikan pengaruh yang signifikan variabel kepuasan peserta didik.

$\mathrm{H}_{1}: \beta 1 \neq 0$ artinya variabel kualitas layanan pendidikan memberikan pengaruh yang signifikan terhadap kepuasan peserta didik.

Dari tabel 1.2., diperoleh nilai $t_{\text {hitung }}$ sebesar $-2,011>t_{\text {tabel }}(-1,960)$ pada pengujian hipotesis arah kiri serta nilai taraf signifikansi sebesar $0,048<a(0,05)$. Artinya $\mathrm{H}_{0}$ ditolak dan $\mathrm{H}_{1}$ diterima, sehingga dapat disimpulkan bahwa kualitas layanan pendidikan memberikan pengaruh yang signifikan terhadap kepuasan peserta didik.

\section{Analisis Determinasi}

Koefisiensi determinasi $\left(\mathrm{R}^{2}\right)$ digunakan untuk mengetahui seberapa besar konstribusi variabel independen terhadap variabel dependen.

\begin{tabular}{|c|c|c|c|c|}
\hline \multicolumn{5}{|c|}{ Tabel 1.14. Koefisien Determinasi } \\
\hline \multicolumn{5}{|c|}{ Model Summary ${ }^{b}$} \\
\hline Model & $\mathrm{R}$ & R Square & Adjusted R Square & $\begin{array}{l}\text { Std. Error of the } \\
\text { Estimate }\end{array}$ \\
\hline 1 & $.761^{\mathrm{a}}$ & .580 & .575 & 3.007 \\
\hline \multicolumn{5}{|c|}{$\begin{array}{l}\text { a. Predictors: (Constant), Kualitas Layanan }\left(\mathrm{X}_{1}\right) \\
\text { b. Dependent Variable: Kepuasan Peserta Didik (Y) }\end{array}$} \\
\hline & & & Sum & Data diolah (2018) \\
\hline
\end{tabular}

Hasil uji koefisien determinasi diperoleh angka $R$ Square sebesar 0,58 yang berarti varian yang terjadi pada variabel kepuasan peserta didik sebesar 58\% ditentukan oleh variabel kualitas layanan pendidikan sedangkan sisanya atau sebesar $42 \%$ itu ditentukan oleh variabel lain yang tidak diteliti.

\section{Pembahasan}

\section{Kualitas Layanan}

Hasil analisa deskripsi jawaban responden diperoleh rata-rata jawaban memilih setuju terhadap pernyataan yang berkaitan 
dengan kualitas layanan yang sudah diberikan oleh sekolah dengan nilai ratarata 3,04 di rentang 2,51-3,25. Indikator kualitas layanan yang harus dipertahankan oleh sekolah yaitu berkaitan dengan tingkat keandalan (reability) yang sudah diberikan, karena rata-rata nilai skor jawaban responden 3,20 dengan nilai tertinggi. Sedangkan indikator daya tanggap (responsiveness) kualitas layanan perlu ditingkatkan lebih baik lagi karena memiliki rata-rata skor jawaban terendah sebesar 2,88 .

2. Kepuasan Peserta Didik

Hasil analisa deskripsi jawaban responden terhadap kepercayaan peserta didik terhadap sekolah diperoleh rata-rata jawaban setuju dengan nilai rata-rata 2,81 berada di rentang 2,51-3,25. Indikator kepuasan peserta didik yang harus dipertahankan oleh sekolah yaitu berkaitan dengan nilai dan keadalan dengan rata-rata nilai skor jawaban tertinggi responden 2,83. Sedangkan indikator yang perlu ditingkatkan yaitu indikator kesesuaian layanan karena memiliki rata-rata skor jawaban terendah sebesar 2,78

3. Pengaruh Kualitas Layanan terhadap Kepuasan Peserta Didik

Hasil perhitungan regresi linier sederhana diperoleh persamaan linier $\mathrm{Y}=-5,904+$ $0,431 X$. Atinya apabila kualitas layanan pendidikan ditingkatkan 1 satuan, maka kepuasan peserta didik akan mengalami peningkatan sebesar 0,431 satuan pada konstanta -5,904. Demikian sebaliknya, apabila kualitas layanan pendidikan diturunkan 1 satuan, maka kepuasan peserta didik akan mengalami penurunan sebesar 0,431 satuan pada konstanta -5,904. Adapun konstribusi kualitas pelayanan terhadap kepuasan peserta didik hanya sebesar $58 \%$, sedangkan sisanya atau sebesar $42 \%$ itu ditentukan oleh variabel lain yang tidak diteliti. Hasil uji hipotesis diperoleh nilai $t_{\text {hitung }}$ sebesar $-2,011>t_{\text {tabel }}(-1,960)$ dengan nilai taraf signifikansi sebesar $0,048<a(0,05)$, artinya $\mathrm{H}_{\mathrm{o}}$ ditolak dan $\mathrm{H}_{1}$ diterima, sehingga dapat disimpulkan bahwa kualitas layanan pendidikan memberikan pengaruh yang signifikan terhadap kepuasan peserta didik.

\section{SIMPULAN}

\section{Kesimpulan}

1. Kualitas layanan pendidikan tergolong baik dengan rata-rata jawaban responden
3,04 pada rentang 2,51-3,25. Indikator yang harus tetap dipertahankan yaitu dalam keandalan (reability) yang dimiliki oleh sekolah.

2. Kepuasan peserta didikjuga tergolong baik, dengan rata-rata jawaban responden 2,81 berada pada rentang 2,51-3,25. Indikator yang perlu dipertahankan yaitu nilai dan layanan. Indikator terendah kesesuaian layanan.

3. Terdapat pengaruh yang positif antara kualitas layanan pendidikan terhadap kepuasan peserta didik, ditunjukkan persamaan linier $\mathrm{Y}=-5,904+0,431 \mathrm{X}$, adapun konstribusi yang diberikan oleh kualitas layanan pendidikan terhadap kepuasan peserta didik sebesar $58 \%$ sedangkan sisanya sebesar $42 \%$ ditentukan oleh variabel lainnya selain kualitas layanan pendidikan.

\section{Saran}

Berdasarkan hasil dari penelitian ini, ada beberapa hal penting yang bisa dikemukakan sebagai saran, yaitu sebagai berikut:

1. Kualitas layanan mempunyai pengaruh positif terhadap kepuasan peserta didik. Oleh karena itu, perlu dipertahankan kualitas layanan yang sudah baik dalam peningkatan kepuasan peserta didik dengan cara mempertahankan keandalan (reability) layanan dan meningkatkan daya tanggap (responsiveness) layanan terhadap kepuasan peserta didik.

2. Kualitas layanan berpengaruh signifikan terhadap kepuasan peserta didik dengan konstribusi sebesar 58\%. Oleh karena itu, diperlukan pengkajian variabel lainnya yang dapat mengungkapkan konstribusi yang lebih baik lagi dalam meningkatkan kepuasan peserta didik.

3. Perlu diadakan penelitian lanjutan, untuk mengungkapkan konstribusi variabel bebas lainnya selain kualitas layanan, seperti promosi dan harga terhadap kepuasan peserta didik dalam meningkatkan kepercayaan dan loyalitas terhadap sekolah.

\section{DAFTAR PUSTAKA}

Abdul Majid, Suharto. 2009. Costomer Service Dalam Bisnis Jasa Transportasi. Jakarta: Rajawali Pers.

Ace Suryadi. 2010. Permasalahan Dan Alternatif Kebijakan Peningkatan Relevansi Pendidikan (Studi Relevansi Pendidikan Kerjasama UPI dengan balitbang $\mathrm{Ke}$ mendiknas. http://file.upi.edu/ Direktori/ Proceeding/Seminar_Internas. NFE. 
Assael, Henry. 2002. Costumer Behavior And Marketing Action, Keat Publishing Company. Boston.

C. Mowen, John dan Michael Minor. 2002. Perilaku Konsumen. Jakarta: Erlangga.

E. Mulyasa. 2004. Kurikulum Berbasis Kompetensi. Bandung: Remaja Rosdakarya Offset.

Engel, J.F, et.al. 1994. Perilaku Konsumen. Edisi Keenam. Binarupa, Jakarta.

Gaol, Chr Jimmy L. 2014. A to Z Human Capital Manajemen Sumber Daya Manusia. Jakarta: Grasindo, Anggota Ikapi.

Ghozali, Imam. 2001. Aplikasi Analisis Multivariate Dengan Program SPSS. Penerbit Badan Penerbit Universitas Diponegoro.

H.A.R Tilaar. 2009. Kekuasaan dan Pendidikan: Manajemen Pendidikan Nasional dalam Pusaran Kekuasaan. Jakarta: Rineka Cipta.

Hasibuan, Malayu. S.P. 2014. Manajemen Sumber Daya Manusia. Edisi Revisi. Bumi Aksara, Jakarta.

Helgesen.,Oyvind, Erik Nesset. 2007. Image, Satisfaction, And Attecedents: Drivers Of Students Loyalthy? A Case Study Of A Norwegian University collage. Corporte Reputation Review (2007). Vol. 10 No. 1 p. 38-59.

Kotler dan Armstrong. Prinsip-Prinsip Pemasaran. Alih Bahasa oleh Wisnu Chandra Kristiaji. Jilid 2. Edisi Kedelapan. Jakarta: Erlangga.

Kotler, Philip. 2007. Manajemen Pemasaran. Edisi Keduabelas. Jilid Kesatu. Jakarta: PT. Indeks.

Loudon, D.L, dan Della Bitta, A.J. 1993. Consumer Behavior: Concepts and Application. Singapore: Mc.Grow-Hill, Inc.

Lovelock, Christopher. \& Wright, Lauren. 2005. Manajemen Pemasaran Jasa. Jakarta. PT. Indeks Kelompok Gramedia.

Lupiyoadi, Rambat. 2001. Manajemen Pemasaran Jasa: Teori dan Praktik. Edisi Pertama. Jakarta. Penerbit Salemba Empat.

Minarti, Sri. 2011. Manajemen Sekolah. Mengelola Lembaga Pendidikan, Secara Mandiri. Yogyakarta. Ar-Ruzz Media.

Ruslan, Rosady. 2008. Manajemen Public Relatoins \& Media Komunikasi. Jakarta. PT Raja grafindo Persada.

Soemirat Soleh, Ardinanto Ervinaro. 2008. Dasar-Dasar Public Relation. Bandung. Remaja Rosdakarya, Rosda.

Sugiyono.2011. Metode Penelitian Kuantitatif, Kualitatif dan R\&D. Bandung, Afabeta.

Tjiptono, Fandy. 2011. Service Quality, and Customer Satisfaction. Edisi Tiga.
Yogyakarta, Andi.

Tjiptono, Fandy dan Chandra, Gregorius. 2004. Service, Quality Satisfaction. Penerbit Andi, Yogyakarta.

Wells, K.N,. dan Prensky, G.A. 1996. Perilaku Organisasi dan Psikologi Personalia. Jakarta. Bina Aksara. 